\title{
Non-Steady-State Measurement of in vivo Radioligand Binding with Positron Emission Tomography: Specificity Analysis and Comparison with in vitro Binding
}

\author{
Joel S. Perlmutter, ${ }^{1.2}$ Stephen M. Moerlein,, ${ }^{2,3}$ Dah-Ren Hwang, ${ }^{2}$ and Richard D. Todd ${ }^{4,5}$ \\ 'Department of Neurology and Neurological Surgery, ${ }^{2}$ Mallinckrodt Institute of Radiology, ${ }^{3}$ Department of Biochemistry \\ and Molecular Biophysics, ${ }^{4}$ Department of Psychiatry, and ${ }^{5}$ Department of Genetics, Washington University School of \\ Medicine, St. Louis, Missouri 63110
}

We previously have developed a non-steady-state method for in vivo measurement of radioligand-receptor binding in brain using positron emission tomography (PET) and ${ }^{10} \mathrm{~F}$ spiperone ( ${ }^{18} \mathrm{~F}-\mathrm{SP}$ ). This method has proven to be highly sensitive to the detection of decreases in the apparent number of available specific binding sites. The purposes of this investigation are to demonstrate the specificity of this PET assay and compare findings to in vitro binding assays. Three to six studies were performed in each of five male baboons. Each animal was pretreated with either ketanserin [serotonergic $\left(S_{2}\right)$ ], eticlopride [dopaminergic $\left(D_{2}\right)$ ], or unlabeled SP to compete with ${ }^{18} \mathrm{~F}-\mathrm{SP}$ for specific binding sites. Sequential PET scans and arterial-blood samples were collected for 3 hr after intravenous injection of ${ }^{18} \mathrm{~F}-\mathrm{SP}$. Data were analyzed with a three-compartment model that considered the accumulation of radiolabeled metabolites in arterial blood. Five baboons were killed, and radioligand-receptor binding in vitro was measured by homogenate techniques. There was no detectable in vitro or in vivo specific binding of SP in cerebellum. The specific binding of SP in striatal tissue in vitro was approximately $74 \%$ to $D_{2}$ sites and $26 \%$ to $S_{2}$ sites, whereas ketanserin displaced all specific binding in frontal cortex. In close agreement, specific binding measured in vivo with PET revealed that $68 \%$ of apparent striatal binding could be blocked by pretreatment with eticlopride, and $34 \%$ by ketanserin. The small apparent difference between receptor binding in vitro and in vivo may result from the relatively poor resolution of PET. No differences in the number of binding sites in left and right brain regions were detected by either PET or in vitro assays. These results provide operational validation for this PET assay of radioligand binding in vivo and demonstrate the lack of right/left differences in striatal SP binding.

\footnotetext{
Received Aug. 31, 1990; revised Dec. 11, 1990; accepted Dec. 14, 1990.

We thank Lennis Lich, John Hood, Jr., Juanita Carl, Lori McGee-Minnich, and Rosalie Focken for invaluable technical assistance. We also appreciate the help of all the members of the Division of Radiation Sciences (Mallinckrodt Institute of Radiology). This work was supported by the McDonnell Center for the Study of Higher Brain Function, NIH Grants HL 13851, AG08377, and RR04865, Teacher Investigator Development Award NS00929 to J.S.P., National Institute of Mental Health Grant MH31302, and FIRST Award 1R29NS26788 to S.M.M., as well as by the generous support of the Greater St. Louis Chapter of the American Parkinson's Disease Association.

Correspondence should be addressed to Joel S. Perlmutter, M.D., Division of Radiation Sciences, Mallinckrodt Institute of Radiology, 510 S. Kingshighway, St. Louis, MO 63110.

Copyright (C) 1991 Society for Neuroscience $0270-6474 / 91 / 111381-09 \$ 03.00 / 0$
}

We have developed a non-steady-state method for measurement of radioligand binding in vivo using positron emission tomography (PET) and ${ }^{18} \mathrm{~F}$-spiperone $\left({ }^{18} \mathrm{~F}\right.$-SP). A three-compartment model that represents the in vivo behavior of an intravenously injected radioligand forms the basis of this assay technique (Mintun et al., 1984; Perlmutter et al., 1986, 1989). This method has been used to demonstrate an increase in radioligand binding in a patient with untreated parkinsonism induced by 1-methyl4-phenyl-1,2,3,6-tetrahydropyridine (MPTP; Perlmutter et al., 1987).

Validation of this or any other PET-based measurement of in vivo radioligand binding (Farde et al., 1986, 1989; Maziere et al., 1986; Wong et al., 1986a,b; Eckernas et al., 1987; Logan et al., 1987; Coenen et al., 1988; Frost et al., 1989; Huang et al., 1989; Swart et al., 1990) has been a difficult task because of the lack of an appropriate "gold standard." Although there is a vast accumulation of data from experiments that employed in vitro techniques, these results depend heavily upon assay conditions (Seeman et al., 1984), which clearly differ from the in vivo milieu (Bennett and Wooten, 1986; Perlmutter and Raichle, 1986). Nevertheless, some workers have compared in vitro binding measurements with those derived from in vivo methods (e.g., Farde et al., 1986; Wong et al., 1986b). This approach can yield interesting information but has limitations, because such comparisons depend upon several crucial assumptions that must be reviewed cautiously.

An alternate approach is to determine the ability of the in vivo PET assay to detect predictable alterations in radioligand binding. In this regard, we previously have demonstrated the sensitivity of our non-steady-state method to a decrease in the apparent maximum number of available specific binding sites (Perlmutter et al., 1989). That study, however, did not demonstrate the specificity of the in vivo PET assay. Therefore, the purposes of this study are to evaluate the specificity of our PET method and to compare it to that measured with in vitro techniques using the same ligands and animals. We also have investigated potential left/right-brain differences in receptor binding as detected with either assay technique. These results provide a basis for interpreting studies of baboons with unilateral brain lesions.

\section{Materials and Methods}

Positron emission tomography. All PET studies were performed with the PETT VI system in the high-resolution mode (Ter-Pogossian et al., 1982; Yamamoto et al., 1982). Data were recorded simultaneously for 
seven tomographic "slices" with a center-to-center separation of 14.4 $\mathrm{mm}$. In-plane (i.e., transverse) reconstructed resolution was about 12 $\mathrm{mm}$ in the center of the field of view, and axial resolution was about $14 \mathrm{~mm}$ at the center.

Radioligand. No-carrier-added ${ }^{18} \mathrm{~F}$-SP was prepared as described previously (Perlmutter et al., 1989). Specific activities determined by HPLC ranged from 1000 to $5000 \mathrm{Ci} / \mathrm{mmol}$ at the time of injection. The chemical purity of ${ }^{18} \mathrm{~F}-\mathrm{SP}$ determined by HPLC showed, in the worst case, a total mass of less than $2 \mu \mathrm{g} \mathrm{SP}$ and less than $2 \mu \mathrm{g}$ nitro-SP. The nitroSP has at least 100-fold lower affinity for SP binding sites than SP (Pogun et al., 1982).

Experimental procedures. Three to six separate PET studies were done on five different male baboons weighing from 8 to $12 \mathrm{~kg}$. We performed at least two control experiments (i.e., without pretreatment) on each animal. The controls were interspersed among the pretreatment studies for each animal. For each study, the animal was fasted overnight but permitted free access to water until $2 \mathrm{hr}$ prior to the experiment. The animal initially was anesthetized with ketamine $(10-15 \mathrm{mg} / \mathrm{kg}, \mathrm{i} . \mathrm{m}$.), injected with atropine $(0.2 \mathrm{mg}$, i.m.) to decrease secretions, paralyzed with gallamine ( $2-4 \mathrm{mg} / \mathbf{k g}$, i.v.), intubated with a soft-cuffed endotracheal tube, and ventilated through a heat and moisture exchanger (Breathaid, BA*1530, Terumo Corporation, Tokyo, Japan) with $70 \%$ nitrous oxide and $30 \%$ oxygen throughout the study. A 20 -gauge plastic catheter was inserted after local anesthesia with lidocaine (1\%) into a femoral artery to permit arterial-blood sampling, and a similar catheter was placed into an arm vein for administration of drugs and radiotracers. Blood pressure and pulse were monitored with an intraarterial pressure transducer. Body temperature was monitored with a rectal probe (TeleThermometer, YSI, Yellow Springs, $\mathrm{OH}$ ) and maintained between $35.5^{\circ} \mathrm{C}$ and $37.5^{\circ} \mathrm{C}$ with a heating blanket. Frequent arterial blood gas measurements confirmed that $\mathrm{pCO}_{2}$ and $\mathrm{pCO}_{2}$ were constant throughout each procedure.

Unlabeled SP $(0.2-1 \mathrm{mg} / \mathrm{kg})$, ketanserin (10-25 mg/kg), (-)-sulpiride $(5-10 \mathrm{mg} / \mathrm{kg})$, and eticlopride $(0.37-4.0 \mathrm{mg} / \mathrm{kg})$ were dissolved in $5 \mathrm{ml}$ of $0.9 \%$ saline or lactate-buffered saline. All compounds were from Research Biochemicals Inc. (Natick, MA) and were injected intravenously with careful monitoring of blood pressure and pulse. Unlabeled SP was injected intravenously over $5-10 \mathrm{~min}$ within $30 \mathrm{~min}$ of induction of anesthesia and $3 \mathrm{hr}$ prior to administration of ${ }^{18} \mathrm{~F}-\mathrm{SP}$. Ketanserin was administered $1 \mathrm{hr}$ prior to ${ }^{18} \mathrm{~F}-\mathrm{SP} ;(-)$-sulpiride and eticlopride were injected $2 \mathrm{hr}$ prior to ${ }^{18} \mathrm{~F}-\mathrm{SP}$.

The head of the baboon was positioned and secured within the scanner using a modified stereotaxic head holder with mouth and ear bars. A lateral skull radiograph with the position of the PET slices marked by radiopaque wires provided a permanent record of the animal's position within the scanner (Perlmutter et al., 1989). Both the modified stereotaxic head holder and the lateral skull radiograph permitted precise repositioning of the animals for repeated studies. Attenuation characteristics of the head were determined prior to each study by obtaining a transmission scan with a ring source of ${ }^{68} \mathrm{Ge} /{ }^{68} \mathrm{Ga}$.

For each experiment, regional cerebral blood flow (CBF) was measured using a 40-sec PET scan after the intravenous injection of 25-40 mCi $\mathrm{H}_{2}{ }^{15} \mathrm{O}$ (Herscovitch et al., 1983; Raichle et al., 1983; Videen et al., 1987). Regional cerebral blood volume (CBV) was determined following the forced inhalation of $50-85 \mathrm{mCi} \mathrm{C} \mathrm{C}^{15} \mathrm{O}$ and a 5-min scan (Martin et al., 1987; Videen et al., 1987). CBF and CBV were measured just prior to injection of ${ }^{18} \mathrm{~F}-\mathrm{SP}$.

At least $3.5 \mathrm{hr}$ after induction of anesthesia, $1.9-16.4 \mathrm{mCi}$ of nocarrier-added ${ }^{18}$ F-SP (Perlmutter et al., 1989) was injected intravenously over 15 sec. Sequential PET scans were started immediately with the injection and continued repeatedly for $3 \mathrm{hr}$. Scan durations were 60 $120 \mathrm{sec}$ initially; longer scans (up to $10 \mathrm{~min}$ ) were required at the end of the study to maintain coincidence counts above 100,000 per slice. The midpoint (weighted for radioactive decay of ${ }^{18} \mathrm{~F}$ ) of each scan was recorded as the time elapsed from the start of radioligand injection.

Arterial-blood samples $(0.3 \mathrm{ml})$ were collected every $3-5 \mathrm{sec}$ for the first $60-120 \mathrm{sec}$ after administration of ${ }^{18} \mathrm{~F}$-SP and then with decreasing frequency during the remainder of the study (Perlmutter et al., 1989). These samples were counted in an NaI(T1) well-type scintillation counter that was cross-calibrated with PETT VI (Mintun et al., 1984). Eleven arterial-blood samples also were analyzed to determine the percentage of total radioactivity present as ${ }^{18} \mathrm{~F}-\mathrm{SP}$ and as radiolabeled metabolites (Perlmutter et al., 1989). Each sample was assayed in duplicate, and the mean values for each time point were fit empirically by an equation (Perlmutter et al., 1989). This equation and the measurements of total
${ }^{18} \mathrm{~F}$ radioactivity were used to calculate the arterial-blood counts due to ${ }^{18} \mathrm{~F}-\mathrm{SP}$ at any given time.

The free fraction of ${ }^{18} \mathrm{~F}-\mathrm{SP}$ in blood, $f_{1}$, was determined for each study using a microfiltration technique (Perlmutter et al., 1989). These determinations were performed in duplicate or triplicate.

Studies on the same animal were performed at least 3 weeks apart to permit sufficient time for recovery. These experiments were approved by the Animal Studies Committee of the Washington University School of Mcdicinc.

Anatomical placement of regions of interest (ROIs; all $1.1 \mathrm{~cm} \times 1.1$ $\mathrm{cm}$ in plane), including midline cerebellum, left and right striata, and frontal cortex, was found using proportional measurements and comparisons with a stereotaxic atlas of the baboon brain (Davis and Huffman, 1968; Perlmutter et al., 1989). This permitted identification of a set of ROIs for a control study (i.e., without pretreatment of unlabeled ligand) for each animal. Once this set of ROIs was established, an automated routine extracted regional measurements from identically placed regions on all sequential PET images collected after injection of ${ }^{18} \mathrm{~F}-\mathrm{SP}$, as well as from the CBF and CBV images. The same set of ROIs for each animal was used for all subsequent studies in that same animal.

PET data analysis. A three-compartment model describing the in vivo behavior of ${ }^{18} \mathrm{~F}$-SP was used to analyze the data from striatal regions, and a two-compartment model (no spccific binding of ${ }^{18} \mathrm{~F}$-SP assumed in cerebellum) was used to analyze cerebellar data (Mintun et al., 1984; Perlmutter et al., 1986, 1989). The details of implementation and assumptions of this method have been described (Mintun et al., 1984; Perlmutter et al., 1986, 1987, 1989). Briefly, this method utilizes the following direct measurements: time-dependent regional brain radioactivity, time-dependent concentrations of radioligand and its metabolites in arterial blood, free fraction of radioligand in blood $\left(f_{1}\right)$, and regional $\mathrm{CBF}$ and $\mathrm{CBV}$. We then estimate the free fraction of radioligand, $f_{2}$ (i.e., the amount free divided by the sum of the free and nonspecifically bound radioligand), in cerebellum and assume that it is the same in striatum. Then, for striatal regions, we estimate the local permeability-surface-area product (PS) for ${ }^{18} \mathrm{~F}-\mathrm{SP}$, the apparent combined forward-rate constant $\left(k_{1}{ }^{\prime}\right.$; i.e., the product of the association rate constant of radioligand for specific binding sites and the apparcnt maximum number of available specific binding sites), and the dissociation rate constant, $k_{-1}$, of radioligand-receptor complex (Perlmutter et al., 1986, 1989). Parameter estimation was performed as previously described (Perlmutter et al., 1986).

Additionally, time-dependent radioactivity measurements for frontal, striatal, and cerebellar regions were compared after decay correction and normalization to the $\mathrm{mCi}$ of ${ }^{18} \mathrm{~F}-\mathrm{SP}$ injected.

In vitro analysis. Animals were killed by injection of pentobarbital (100 mg/kg, i.v.); the brains were quickly removed and dissected, and samples were placed on dry ice and stored at $-70^{\circ} \mathrm{C}$ until further analysis. Membranes were prepared as previously described (Todd and Bauer, 1988 ) and assayed for ${ }^{3} \mathrm{H}$-spiperone (specific activity, $23-25 \mathrm{Ci} / \mathrm{mmol}$; New England Nuclear) binding in the presence and absence of various unlabeled compounds. Samples (40-100 $\mu$ g protein) were assayed in triplicate in a total volume of $1 \mathrm{ml}$ that contained $120 \mathrm{~mm} \mathrm{NaCl}, 50$ mM Tris ( $\mathrm{pH}, 7.4)$, and $0.1-10.0 \mathrm{nM}{ }^{3} \mathrm{H}$-spiperone $\pm 1 \mu \mathrm{M}$ unlabeled competitor. All incubations were for $15 \mathrm{~min}$ at $37^{\circ} \mathrm{C}$. Samples were diluted with cold buffer, rapidly collected onto glass-fiber filters, and washed twice more with cold buffer using a modified Brandel cell harvester. Preliminary studies demonstrated that under these conditions ${ }^{3} \mathrm{H}$-spiperone binding displaceable by eticlopride or by ketanserin was saturable, reversible, and maximal by 10-12 min of incubation. The inclusion of $1-2 \mathrm{mM} \mathrm{CaCl}$ or $1-4 \mathrm{mM} \mathrm{MgCl}$ did not affect binding.

The equilibrium binding variables $K_{d}$ and $B_{\max }$ were determined from membrane binding data using the nonlinear curve-fitting program LIGAND (Munson and Rodbard, 1980). A constant percent error model of variance was assumed. Left/right regional brain values were compared by two-tailed $t$ tests using pooled data.

\section{Results}

Measurements of regional CBF, CBV, and the free fraction of ${ }^{18} \mathrm{~F}-\mathrm{SP}$ in arterial blood $\left(f_{1}\right)$, as well as the estimates of the free fraction in brain tissue $\left(f_{2}\right)$ and regional PS for ${ }^{18} \mathrm{~F}-\mathrm{SP}$, are shown in Tables 1 and 2. No consistent changes in these variables were found after pretreatment with ketanserin, eticlopride, or unla- 


\begin{tabular}{|c|c|c|c|c|c|c|}
\hline \multirow[b]{2}{*}{ Dose } & \multirow[b]{2}{*}{ Subject } & \multirow[b]{2}{*}{$n$} & \multicolumn{2}{|l|}{ Striatal CBF } & \multicolumn{2}{|l|}{ Striatal CBV } \\
\hline & & & Left (SD) & Right (SD) & Left (SD) & Right (SD) \\
\hline \multirow[t]{5}{*}{ None } & A & 2 & $0.011(0.004)$ & $0.012(0.005)$ & $0.033(0.001)$ & $0.033(0.001)$ \\
\hline & B & 3 & $0.025(0.010)$ & $0.023(0.010)$ & $0.038(0.003)$ & $0.035(0.003)$ \\
\hline & $\mathrm{C}$ & 3 & $0.015(0.005)$ & $0.015(0.005)$ & $0.038(0.007)$ & $0.037(0.008)$ \\
\hline & D & 3 & $0.016(0.006)$ & $0.016(0.006)$ & $0.041(0.014)$ & $0.048(0.019)$ \\
\hline & $\mathrm{E}$ & 2 & $0.016(0.001)$ & $0.015(0.001)$ & $0.040(0.006)$ & $0.044(0.004)$ \\
\hline \multicolumn{7}{|c|}{ Ketanserin } \\
\hline 10 & B & 1 & 0.011 & 0.012 & 0.040 & 0.045 \\
\hline 14 & $\mathrm{C}$ & 1 & 0.019 & 0.019 & 0.074 & 0.071 \\
\hline 25 & A & 1 & 0.018 & 0.018 & 0.047 & 0.041 \\
\hline \multicolumn{7}{|c|}{ Eticlopride } \\
\hline 0.4 & D & 1 & 0.010 & 0.010 & 0.034 & 0.036 \\
\hline 2 & D & 1 & 0.015 & 0.014 & 0.050 & 0.049 \\
\hline 4 & $\mathbf{E}$ & 1 & 0.012 & 0.012 & 0.021 & 0.021 \\
\hline \multicolumn{7}{|l|}{ SP } \\
\hline 0.2 & B & 1 & 0.011 & 0.011 & 0.027 & 0.027 \\
\hline 0.2 & $\mathrm{C}$ & 1 & 0.015 & 0.015 & 0.053 & 0.052 \\
\hline 0.2 & $\mathrm{D}$ & 1 & 0.013 & 0.012 & 0.047 & 0.047 \\
\hline
\end{tabular}

Dose refers to intravenous dose $(\mathrm{mg} / \mathrm{kg})$ of unlabeled ligand administered prior to ${ }^{18} \mathrm{~F}-\mathrm{SP}$. Subject refers to the identity of each baboon (A-E). Regional CBF (ml/sec/cc) was measured using $\mathrm{H}_{2}{ }^{15} \mathrm{O}$ and a $40-\mathrm{sec}$ PET scan. Regional CBV (ml/ cc) was measured with $\mathrm{C}^{15} \mathrm{O}$ and a 5 -min PET scan.

beled SP. Individual changes in these values reflect biological variability among subjects, biological variability over time within the same subject, and limitations of the reproducibility of the PET methodology. Measurements of the fraction of radiolabeled metabolites of ${ }^{18} \mathrm{~F}-\mathrm{SP}$ in arterial blood did not change consistently after pretreatment with any of the unlabeled ligands.
Estimates of relevant binding variables, including the apparent combined forward-rate constant, $k_{1}{ }^{\prime}$ (i.e., the product of the association rate constant and the apparent maximum number of specific binding sites), and the dissociation rate constant, $k_{-1}$, are shown in Table 3. We found no significant right/left differences by paired $t$ tests in the combined forward-rate constants

Table 2. Effect of receptor ligands on free fraction and PS values of ${ }^{18} \mathrm{~F}-\mathrm{SP}$

\begin{tabular}{|c|c|c|c|c|c|c|}
\hline \multirow[b]{2}{*}{ Dose } & \multirow[b]{2}{*}{ Subject } & \multirow[b]{2}{*}{$n$} & \multirow[b]{2}{*}{$f_{1}(\mathrm{SD})$} & \multirow[b]{2}{*}{$f_{2}(\mathrm{SD})$} & \multicolumn{2}{|l|}{ Striatal PS } \\
\hline & & & & & Left (SD) & Right (SD) \\
\hline \multirow[t]{5}{*}{ None } & A & 2 & $0.040(0.010)$ & $0.010(0.001)$ & $0.083(0.003)$ & $0.082(0.004)$ \\
\hline & B & 3 & $0.044(0.007)$ & $0.012(0.0005)$ & $0.060(0.012)$ & $0.058(0.009)$ \\
\hline & C & 3 & $0.035(0.002)$ & $0.009(0.002)$ & $0.067(0.023)$ & $0.069(0.022)$ \\
\hline & $\mathrm{D}$ & 3 & $0.066(0.014)$ & $0.015(0.004)$ & $0.040(0.009)$ & $0.040(0.010)$ \\
\hline & $\mathrm{E}$ & 2 & $0.042(0.017)$ & $0.012(0.004)$ & $0.053(0.018)$ & $0.050(0.022)$ \\
\hline \multicolumn{7}{|c|}{ Ketanserin } \\
\hline 10 & B & 1 & 0.049 & 0.017 & 0.030 & 0.032 \\
\hline 14 & $\mathrm{C}$ & 1 & 0.039 & 0.013 & 0.048 & 0.050 \\
\hline 25 & A & 1 & 0.040 & 0.012 & 0.072 & 0.069 \\
\hline \multicolumn{7}{|c|}{ Eticlopride } \\
\hline 0.4 & $\mathrm{D}$ & 1 & 0.062 & 0.014 & 0.097 & 0.096 \\
\hline 2 & $\mathbf{D}$ & 1 & 0.081 & 0.028 & 0.031 & 0.028 \\
\hline 4 & E & 1 & 0.039 & 0.012 & 0.068 & 0.066 \\
\hline \multicolumn{7}{|l|}{ SP } \\
\hline 0.2 & B & 1 & 0.027 & 0.008 & 0.080 & 0.094 \\
\hline 0.2 & $\mathrm{C}$ & 1 & 0.042 & 0.010 & 0.075 & 0.073 \\
\hline 0.2 & $\mathrm{D}$ & 1 & 0.072 & 0.020 & 0.032 & 0.029 \\
\hline
\end{tabular}

Dose refers to intravenous dose $\left(\mathrm{mg} / \mathrm{kg}\right.$ ) of unlabeled ligand administered prior to ${ }^{18} \mathrm{~F}-\mathrm{SP}$. Subject refers to the identity of each baboon (A-E). $f_{1}$ refers to the free fraction of ${ }^{18} \mathrm{~F}-\mathrm{SP}$ in arterial blood measured by microfiltration techniques. $f_{2}$ indicates the free fraction of ${ }^{18} \mathrm{~F}-\mathrm{SP}$ in brain tissue (i.e., the amount free divided by the sum of the nonspecifically bound and free). This is estimated from the PET and arterial-blood data using a two-compartment model applied to the cerebellum. PS is the permeability-surface-area product of the blood-brain barrier for ${ }^{18} \mathrm{~F}-\mathrm{SP}$ (cc/sec for a $1 \mathrm{cc}$ tissue volume), calculated as described in Materials and Methods. 
Figure 1. Effects of ketanserin on striatal uptake. Decay-corrected measurements of radioactivity in counts per sec/ $\mathrm{ml} /[\mathrm{mCi}$ injected] $/[\mathrm{kg}$ body weight] (cps/ $\mathrm{ml} / \mathrm{mCi} / \mathrm{kg}$ ) are shown for the left striatum of baboons after the intravenous injection of ${ }^{18} \mathrm{~F}-\mathrm{SP}$. Three "PreRx" studies (open symbols) were preceded by ketanserin $(10-25 \mathrm{mg} / \mathrm{kg}, \mathrm{i} . \mathrm{v}$.) to block $\mathrm{S}_{2}$ receptors. The other three PET studies (solid symbols) were not preceded by ketanserin administration and served as controls. These data demonstrate that doses of ketanserin greater than $10 \mathrm{mg} / \mathrm{kg}$ did not block additional $\mathrm{S}_{2}$ binding sites in striatum, because the tissue-activity curves were not shifted downward substantially.

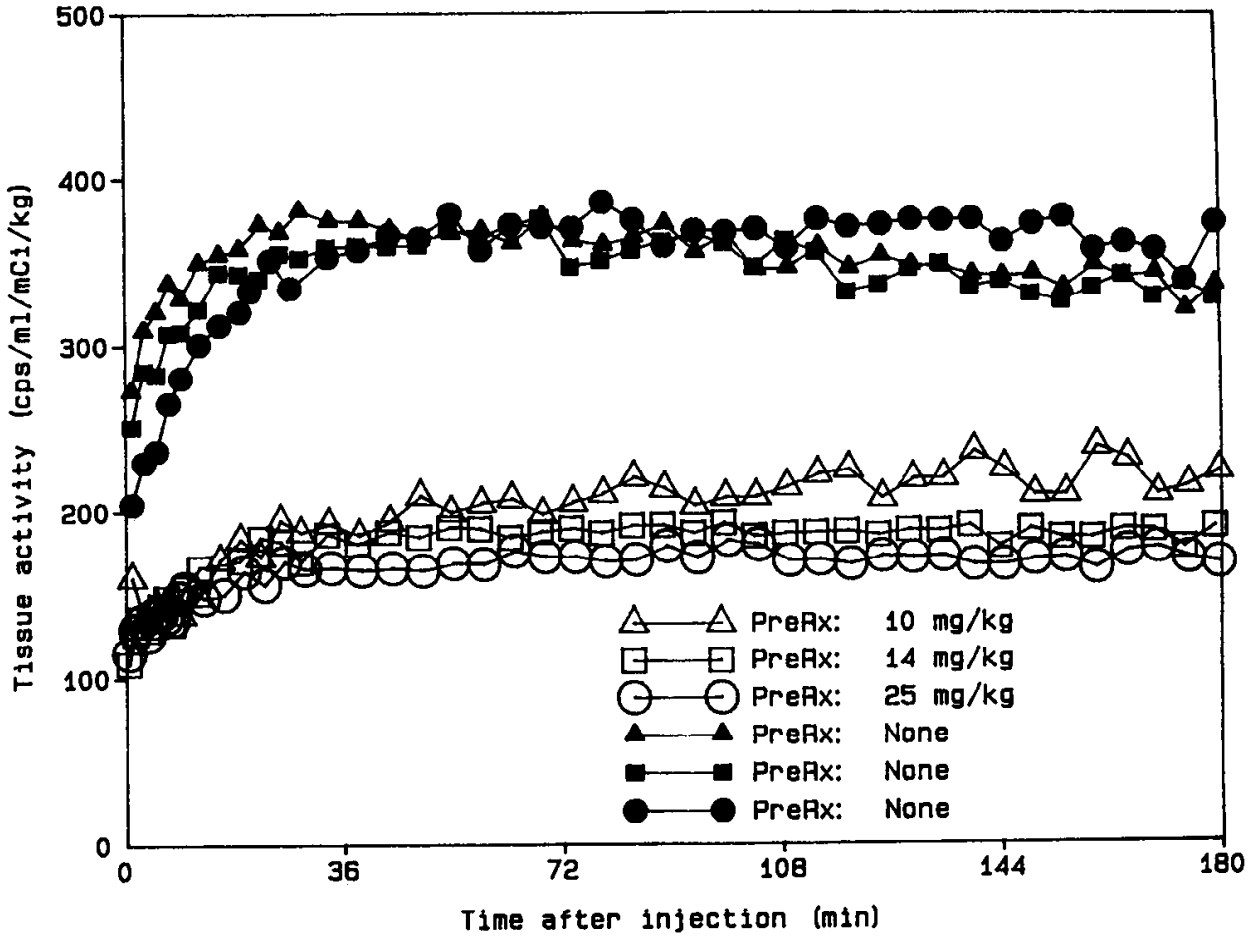

Table 3. Kinetic analysis of ${ }^{18} \mathrm{~F}-\mathrm{SP}$ binding in vivo

\begin{tabular}{|c|c|c|c|c|c|c|}
\hline \multirow[b]{2}{*}{ Dose } & \multirow[b]{2}{*}{ Subject } & & \multicolumn{2}{|l|}{ Left striatum } & \multicolumn{2}{|l|}{ Right striatum } \\
\hline & & $n$ & $\overline{k_{1}^{\prime}}$ & $k_{-1}$ & $k_{1}^{\prime}$ & $k_{-1}$ \\
\hline \multirow[t]{5}{*}{ None } & A & 2 & $0.111 \pm 0.020^{a}$ & $0.00022 \pm 0.00004$ & $0.107 \pm 0.019$ & $0.00020 \pm 0.00003$ \\
\hline & B & 3 & $0.068 \pm 0.010$ & $0.00017 \pm 0.00002$ & $0.066 \pm 0.008$ & $0.00014 \pm 0.00002$ \\
\hline & $\mathrm{C}$ & 3 & $0.194 \pm 0.066$ & $0.00038 \pm 0.00016$ & $0.184 \pm 0.088$ & $0.00036 \pm 0.00013$ \\
\hline & $\mathrm{D}$ & 3 & $0.073 \pm 0.002$ & $0.00024 \pm 0.00009$ & $0.070 \pm 0.006$ & $0.00028 \pm 0.00016$ \\
\hline & $\mathrm{E}$ & 2 & $0.097 \pm 0.058$ & $0.00015 \pm 0.00003$ & $0.075 \pm 0.031$ & $0.00013 \pm 0.00000$ \\
\hline \multicolumn{7}{|l|}{ Ketanserin } \\
\hline 10 & B & 1 & $0.040(59 \%)^{b}$ & $0.00014(82 \%)$ & $0.038(58 \%)$ & $0.00013(93 \%)$ \\
\hline 14 & $\mathrm{C}$ & 1 & $0.097(50 \%)$ & $0.00032(84 \%)$ & $0.085(46 \%)$ & $0.00026(72 \%)$ \\
\hline 25 & A & 1 & $0.096(86 \%)$ & $0.00020(83 \%)$ & $0.108(101 \%)$ & $0.00022(110 \%)$ \\
\hline Mean & & & $65 \%$ & $83 \%$ & $68 \%$ & $92 \%$ \\
\hline \multicolumn{7}{|l|}{ Eticlopride } \\
\hline 0.4 & $\mathrm{D}$ & 1 & $0.031(42 \%)$ & $0.00028(117 \%)$ & $0.030(43 \%)$ & $0.00028(100 \%)$ \\
\hline 2 & $\mathrm{D}$ & 1 & $0.023(32 \%)$ & $0.00066(275 \%)$ & $0.019(27 \%)$ & $0.00060(214 \%)$ \\
\hline 4 & $\mathrm{E}$ & 1 & $0.031(32 \%)$ & $0.00052(347 \%)$ & $0.028(37 \%)$ & $0.00045(346 \%)$ \\
\hline Mean $^{c}$ & & & $32 \%$ & $311 \%$ & $32 \%$ & $280 \%$ \\
\hline \multicolumn{7}{|l|}{ SP } \\
\hline 0.2 & B & 1 & $0.006(9 \%)$ & $0.00003(18 \%)$ & $0.012(18 \%)$ & $0.00013(93 \%)$ \\
\hline 0.2 & $\mathrm{C}$ & 1 & $0.069(36 \%)$ & $0.00054(142 \%)$ & $0.073(40 \%)$ & $0.00057(158 \%)$ \\
\hline 0.2 & D & 1 & $0.012(16 \%)$ & $0.00032(133 \%)$ & $0.013(18 \%)$ & $0.00038(136 \%)$ \\
\hline Mean & & & $20 \%$ & $98 \%$ & $25 \%$ & $129 \%$ \\
\hline
\end{tabular}

Dose refers to intravenous dose $(\mathrm{mg} / \mathrm{kg})$ of unlabeled ligand administered prior to ${ }^{18} \mathrm{~F}-\mathrm{SP}$. Subject refers to the identity of each baboon (A-E). Binding values are per oc of brain tissue, expressed as sec-1. $k_{1}^{\prime}$ denotes the combined forwardrate constant (the product of the apparent maximum number of specific binding sites and the association rate constant of ${ }^{18} \mathrm{~F}$-SP for those specific sites). $k_{\sim 1}$ is the dissociation rate constant of radioligand-receptor complex. Both of these turnover rate constants are cstimated from the PET and arterial-blood data using a three-compartment model as described in Materials and Methods.

${ }^{a}$ Control values are expressed as $\sec ^{-1} \pm \mathrm{SD}$.

${ }^{b}$ Percentages are the percent of the mean control values for that subject.

c Mean of the values after pretreatment with eticlopride includes only the $2 \mathrm{mg} / \mathrm{kg}$ and $4 \mathrm{mg} / \mathrm{kg}$ values. 


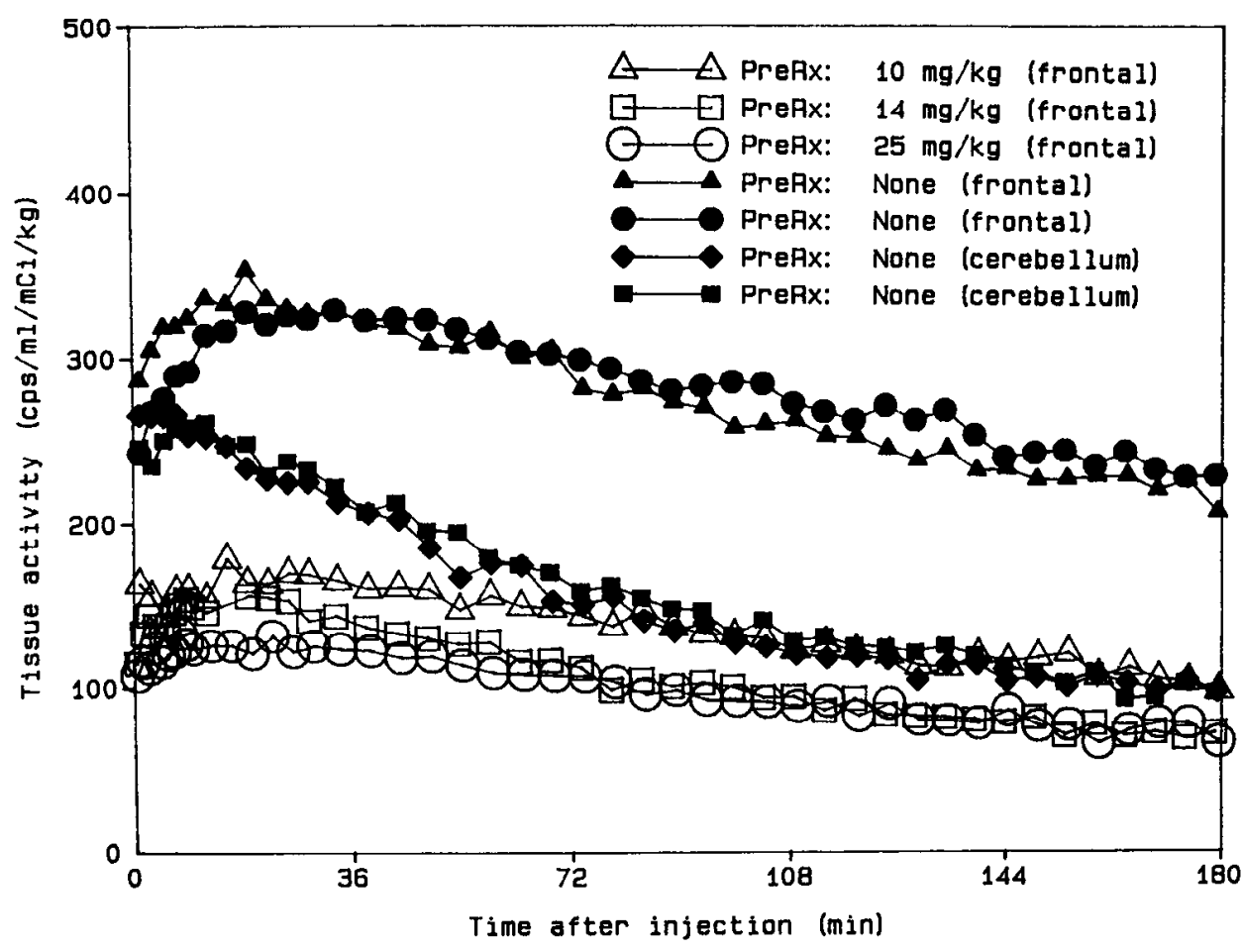

Figure 2. Effects of ketanserin on frontal cortex uptake. Decay-corrected measurements of radioactivity in counts per $\mathrm{sec} / \mathrm{ml} /[\mathrm{mCi}$ injected $] /[\mathrm{kg}$ body weight] $(\mathrm{cps} / \mathrm{ml} / \mathrm{mCi} / \mathrm{kg}$ ) are shown for frontal cortex and cerebellum of baboons after the intravenous injection of ${ }^{18} \mathrm{~F}-\mathrm{SP}$. Three "PreRx" studies (open symbols) were preceded by ketanserin $(10-25 \mathrm{mg} / \mathrm{kg}$, i.v. $)$ to block $\mathrm{S}_{2}$ receptors. The other two PET studies (solid symbols) were not preceded by ketanserin administration and served as controls. There were no substantial differences among the frontal tissue-activity curves obtained after pretreatment with the three different doses of ketanserin and the control cerebellar tissue-activity curves. These data demonstrate that doses greater than $10 \mathrm{mg} / \mathrm{kg}$ of ketanserin block all observable specific $\mathrm{S}_{2}$ binding sites in frontal cortex. $(p=0.31)$ or the dissociation rate constants $(p=0.57)$. Because of the variability across subjects, the effects of pretreatment are best demonstrated by comparisons of individual values to the mean control values for the same subject.

Pretreatment with the $S_{2}$ ligand ketanserin blocked about $35 \%$ (left) and 32\% (right) of the apparent specific striatal binding of ${ }^{18} \mathrm{~F}-\mathrm{SP}$ in vivo. The lack of substantial changes in the striatal tissue-activity curves for increasing doses of ketanserin demonstrate that the doses employed gave maximum $S_{2}$ receptorblocking effects (Fig. 1). Furthermore, these doses caused the tissue-activity curves for the $S_{2}$-rich frontal cortex to appear similar to the cerebellar curves (Fig. 2). This strongly supports the notion that the doses of ketanserin that were employed were sufficient to block all $\mathrm{S}_{2}$ specific binding in vivo in brain tissues.

Pretreatment with the $\mathrm{D}_{2}$ ligand eticlopride $(2$ or $4 \mathrm{mg} / \mathrm{kg}$ ) blocked $68 \%$ (left) and $73 \%$ (right) of the apparent specific binding of ${ }^{18} \mathrm{~F}$-SP in vivo in the striata. The higher dose of eticlopride, $4 \mathrm{mg} / \mathrm{kg}$, produced no additional blocking compared to a dose of $2 \mathrm{mg} / \mathrm{kg}$. In contrast, $0.37 \mathrm{mg} / \mathrm{kg}$ eticlopride did not block all apparent specific binding sites for ${ }^{18} \mathrm{~F}$-SP (Fig. 3, Table 3).

Pretreatment with unlabeled SP $(0.2 \mathrm{mg} / \mathrm{kg})$ decreased the estimated combined forward-rate constant of ${ }^{18} \mathrm{~F}-\mathrm{SP}$ more than either ketanserin or eticlopride (Table 3). Higher doses of SP reduce specific binding to a greater extent but, in doing so, do not permit estimation of the combined forward-rate constant due to the low amount of specific binding compared to nonspecifically bound ${ }^{18} \mathrm{~F}-\mathrm{SP}$. For example, pretreatment with unlabeled SP (1 mg/kg) reduced the striatal tissue-activity curve to the level of a cerebellar tissue-activity curve, presumably by blocking all specific binding sites in striatum. However, the combined forward-rate constant could not be estimated with confidence.

Sulpiride at an intravenous dose of 5,8 , and $9.6 \mathrm{mg} / \mathrm{kg}$ did not cause appreciable change in striatal tissue-activity curves compared to those of controls. Higher intravenous doses of the ligand caused cardiovascular instability and could not be used safely in baboons.

Interestingly, none of the unlabeled ligands altered the uptake of radioactivity in cerebellum, as demonstrated by a lack of change in tissue-activity curves after pretreatment with eticlopride, ketanserin, or unlabeled spiperone (Fig. 4). These in vivo results are consistent with the lack of specific binding sites in baboon brain as determined in vitro (Table 4).

The results of in vitro binding studies closely agreed with the results of in vivo experiments. As shown in Table 4, binding to $\mathrm{D}_{2}$ receptors accounted for about $74 \%$ of ${ }^{3} \mathrm{H}$-SP specific binding in striatum (averaging the $B_{\max }$ data for left and right caudate and putamen). Binding by the radioligand to $S_{2}$ receptors accounted for the remainder. No specific ${ }^{3} \mathrm{H}-\mathrm{SP}$ binding in cerebellum was detected. Additionally, there were no significant left/ right differences in $K_{d}$ or $B_{\max }$ for ${ }^{3} \mathrm{H}-\mathrm{SP}$ binding to either $\mathrm{D}_{2}$ or $\mathrm{S}_{2}$ receptors in these tissues. Given the relatively small number of subjects and the variance in measurements (Table 4), there was a $75-90 \%$ chance to detect at least a $50 \%$ difference in $B_{\max }$ but only a $50-80 \%$ chance to detect at least a $100 \%$ difference in $K_{d *}$

A summary of nonspecific binding by ${ }^{3} \mathrm{H}-\mathrm{SP}$ in vitro is presented in Table 5. There were no significant differences in nonspecific binding to membranes across brain regions. There were also no significant left/right regional differences in nonspecific binding of ${ }^{3} \mathrm{H}-\mathrm{SP}$.

\section{Discussion}

Results of this investigation further validate our non-steadystate technique for measurement of radioligand binding in vivo with PET and ${ }^{18}$ F-SP. We now have demonstrated the specificity of this in vivo assay and compared these results to those of an in vitro binding assay. Furthermore, we also have evaluated the adequacy of the baboon's cerebellum as a region of brain devoid of specific binding sites. This type of operational validation is 
Figure 3. Effects of eticlopride on striatal uptake. Decay-corrected measurements of radioactivity in counts per sec/ $\mathrm{mV} /[\mathrm{mCi}$ injected]/[kg body weight] (cps/ $\mathrm{ml} / \mathrm{mCi} / \mathrm{kg}$ ) are shown for left striatum of baboons after the intravenous injection of ${ }^{18} \mathrm{~F}-\mathrm{SP}$. Three "PreRx" studies (open symbols) were preceded by eticlopride $(0.37-4 \mathrm{mg} / \mathrm{kg}$, i.v.) to block $\mathrm{D}_{2}$ receptors. Two PET studies (solid symbols) were not preceded by eticlopride administration and served as controls. Pretreatment with $0.37 \mathrm{mg} / \mathrm{kg}$ did not appear to maximally' block specific binding sites in striatum, whereas 2 and $4 \mathrm{mg} / \mathrm{kg}$ of the $D_{2}$ ligand were not substantially different from each other. The "tails" of the tissue-activity curves reflect binding to receptors to a greater degree than the "fronts" of the curves due to clearance of free and nonspecifically bound ${ }^{18} \mathrm{~F}-\mathrm{SP}$.

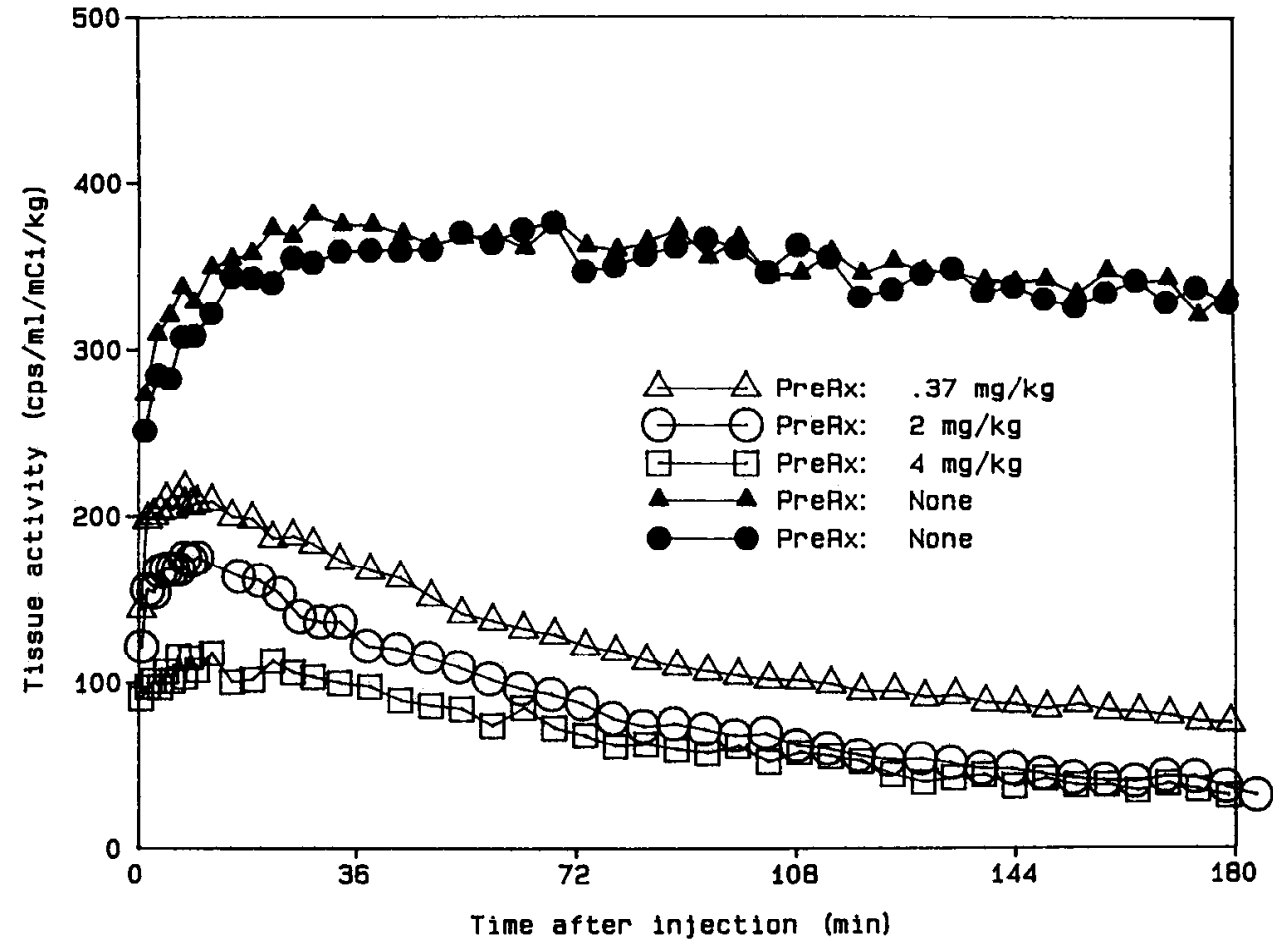

necessary because of the lack of a "gold standard" for in vivo binding and requires complete understanding of the methodological issues that impact interpretation of our findings.

The specificity of this PET measurement depends not only on the receptor specificity of ${ }^{18} \mathrm{~F}-\mathrm{SP}$ in vivo, but also upon the resolution of the PET image. In vitro binding studies demonstrated that about $75 \%$ of the specific binding of ${ }^{3} \mathrm{H}-\mathrm{SP}$ in striatum was to $\mathrm{D}_{2}$ sites, whereas only about $68 \%$ of the specific binding in vivo of ${ }^{18} \mathrm{~F}-\mathrm{SP}$ was blocked by pretreatment with eticlopride. Although the difference may not be statistically significant, it could reflect that the PET measurement of radioactivity from striatum is "contaminated" by inclusion of spillover from nearby temporal cortex, an area that contains $S_{2}$ binding sites for ${ }^{18} \mathrm{~F}-\mathrm{SP}$ that are unaffected by unlabeled eticlopride. This volume averaging (Mazziotta et al., 1981) may contribute, in part, to the higher apparent $S_{2}$ binding in striatum. Fortunately, such volume averaging from nearby tissues will become less important as the resolution of PET scanners continues to improve (Spinks et al., 1988; Litton et al., 1990). An alternate explanation that may contribute to the potential difference between the results from PET and in vitro assays is that in vivo access to specific binding sites is different from that under in vitro assay conditions. Pharmacodynamic factors such as druginduced alterations by ketanserin or eticlopride in radioligand delivery to the striatum are unlikely to cause a change in the measured apparent combined forward-rate constant. This is be-

Table 4. Specific binding in vitro of ${ }^{3} \mathrm{H}-\mathrm{SP}$ to different brain regions

\begin{tabular}{|c|c|c|c|c|c|c|}
\hline \multirow[b]{2}{*}{ Displacer } & \multicolumn{2}{|l|}{ Caudate } & \multicolumn{2}{|l|}{ Putamen } & \multicolumn{2}{|c|}{ Cerebellum } \\
\hline & $K_{d}(\mathrm{pM})$ & $B_{\max }(\mathrm{pmol} / \mathrm{mg})$ & $K_{d}(\mathrm{pM})$ & $B_{\max }(\mathrm{pmol} / \mathrm{mg})$ & $K_{d}(\mathrm{pM})$ & $\begin{array}{l}B_{\max } \\
(\mathrm{pmol} \\
\mathrm{mg})\end{array}$ \\
\hline \multicolumn{7}{|l|}{ Eticlopride } \\
\hline Left & $54.9 \pm 11.7$ & $0.18 \pm 0.03$ & $46.5 \pm 9.5$ & $0.13 \pm 0.02$ & - & ND \\
\hline Right & $58.0 \pm 12.6$ & $0.18 \pm 0.02$ & $68.2 \pm 16.9$ & $0.11 \pm 0.02$ & - & ND \\
\hline$p(t$ test $)$ & NS & NS & NS & NS & & \\
\hline \multicolumn{7}{|l|}{ Ketanserin } \\
\hline Left & $117.5 \pm 54.5$ & $0.08 \pm 0.03$ & $159.4 \pm 153.0$ & $0.05 \pm 0.02$ & - & ND \\
\hline Right & $15.3 \pm 6.8$ & $0.06 \pm 0.02$ & $60.9 \pm 53.1$ & $0.02 \pm 0.02$ & - & ND \\
\hline$p(t$ test $)$ & NS & NS & NS & NS & & \\
\hline \multicolumn{7}{|l|}{ SP } \\
\hline Left & $113.4 \pm 32.5$ & $0.18 \pm 0.03$ & $105.3 \pm 31.7$ & $0.16 \pm 0.03$ & - & ND \\
\hline Right & $268.0 \pm 48.9$ & $0.24 \pm 0.03$ & $243.4 \pm 55.9$ & $0.20 \pm 0.04$ & - & ND \\
\hline$p(t$ test $)$ & NS & NS & NS & NS & & \\
\hline
\end{tabular}

All values are means \pm SEM for membranes from five baboons assayed two to four times for specific ${ }^{3} \mathrm{H}$-SP binding as described in Materials and Methods. ND, not detected; NS, not significant. All $t$ tests compared values for tissues from the right and left sides of the brain. 


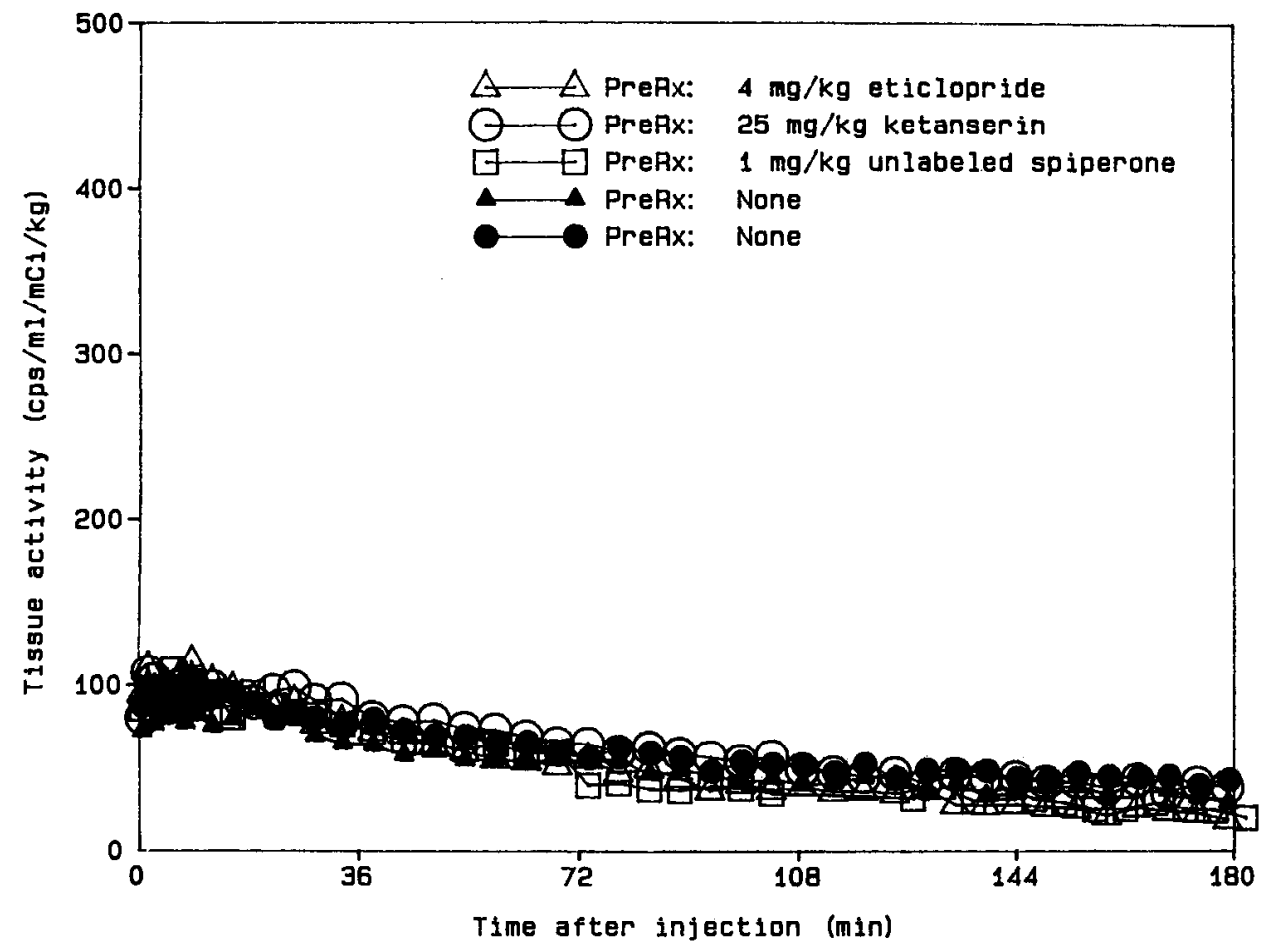

Figure 4. Effects of unlabeled ligands on cerebellar uptake. Decay-corrected measurements of radioactivity in counts per $\mathrm{sec} / \mathrm{ml} /[\mathrm{mCi}$ injected $] /[\mathrm{kg}$ body wcight] $(\mathrm{cps} / \mathrm{ml} / \mathrm{mCi} / \mathrm{kg})$ are shown for the cerebellum of baboons after the intravenous injection of ${ }^{18} \mathrm{~F}-\mathrm{SP}$. Three "PreRx" studies (open symbols) were preceded by intravenous injection of maximal receptor-blocking doses of either eticlopride, ketanserin, or unlabeled SP. The other two PET studies (solid symbols) were not preceded by administration of unlabeled ligands and served as controls. There were no substantial differences among the five tissue-activity curves, which demonstrates that doses of ligands which maximally block available specific binding sites in striatum (Figs. 1, 3; Table 3 ) do not block specific binding sites in cerebellum. cause our method measures or estimates changes in variables such as regional CBF or regional PS for ${ }^{18} \mathrm{~F}-\mathrm{SP}$ and incorporates them into the calculation of the apparent combined forwardrate constant. Additionally, the arterial blood content of ${ }^{18} \mathrm{~F}-\mathrm{SP}$ did not change with the various pretreatment conditions (i.e., metabolism of the radioligand did not change), nor did the free fraction of ${ }^{18} \mathrm{~F}-\mathrm{SP}$ in blood change. The relatively close values for specificity between the in vivo and in vitro methods are noteworthy.

Another important technical issue of the in vivo PET assay is the degree that $S_{2}$ or $D_{2}$ receptors are blocked competitively by the pretreatment doses of ketanserin or eticlopride. We have shown that the dose of ketanserin that we used caused the tissueactivity curve for the frontal cortex (a region that we found by in vitro assay to contain only $\mathrm{S}_{2}$ binding sites for ${ }^{18} \mathrm{~F}-\mathrm{SP}$ ) nearly to overlap the cerebellar curve. Because the cerebellum lacks $S_{2}$ receptors, this result suggests that the dose of the $S_{2}$ ligand that we used blocked all specific binding in vivo by ${ }^{18} \mathrm{~F}-\mathrm{SP}$ in frontal cortex. Because the frontal cortex has greater $\mathrm{S}_{2}$-specific binding than the striatum, it is reasonable to assume, though not absolutely proven, that all striatal $S_{2}$ sites were also blocked. Furthermore, higher doses of ketanserin did not change substantially the striatal or frontal cortex tissue-activity curves for ${ }^{18} \mathrm{~F}$ SP (Figs. 1, 2). Pretreatment with eticlopride $(0.37 \mathrm{mg} / \mathrm{kg}$ ) did not appear to block all specific striatal binding sites, as demonstrated by the modest lowering of the tissue-activity curves (Fig. 3) and the intermediate decrease in the magnitude of the apparent combined forward-rate constant for ${ }^{18} \mathrm{~F}-\mathrm{SP}$ (Table 3). The next-higher dose $(2 \mathrm{mg} / \mathrm{kg})$ appeared to block maximally $\mathrm{D}_{2}$-specific binding of ${ }^{18} \mathrm{~F}$-SP in striatum, as evidenced by the lack of substantial change in either the striatal tissue-activity curve (Fig. 3) or the estimated combined forward-rate constant for ${ }^{18} \mathrm{~F}-\mathrm{SP}$ (Table 3) after pretreatment with $4 \mathrm{mg} / \mathrm{kg}$ of the unlabeled ligand. Doses of eticlopride greater than $4 \mathrm{mg} / \mathrm{kg}$ were not tolerated by the animals.

As previously discussed (Perlmutter et al., 1989), we have chosen to report our values of the combined forward-rate constant as the "apparent forward-rate constant" because of the possible nonequilibrium conditions for the unlabeled ligand (i.e., eticlopride, ketanserin, or SP) during the course of the ${ }^{18} \mathrm{~F}-\mathrm{SP}$ study. Maximal hinding by ketanserin almost certainly has occurred prior to the injection of ${ }^{18} \mathrm{~F}-\mathrm{SP}$. This is because of the relatively fast kinetics of intravenously administered ketanserin and eticlopride, as revealed by preliminary data with the radiolabeled ligands (Baron et al., 1985; Kohler et al., 1986; Moerlein and Perlmutter, 1990).

It should also be noted that the "apparent combined forwardrate constant" and the dissociation rate constant estimated with this PET technique reflect averaged composite values for all specific binding within the ROI. Our data demonstrate that baboon striatum contains $S_{2}$ - and $D_{2}$-specific binding sites for ${ }^{18} \mathrm{~F}-\mathrm{SP}$. The degree to which these two different sites contribute to the binding values that we estimate depends in part upon their availability. After high-dose eticlopride pretreatment, $\mathrm{D}_{2}$ sites contribute less (probably none at the higher doses in this study), and the estimated binding constants therefore reflect the characteristics and number of available $S_{2}$ sites. The individual contributions from $\mathrm{D}_{2}$ and $\mathrm{S}_{2}$ sites are not discernable unless high doses of specific antagonists are used to block binding sites. This could produce undesirable clinical effects in humans and

\begin{tabular}{llll}
\hline $\begin{array}{l}\text { Table 5. } \\
\text { regions }\end{array}$ & Nonspecific binding in vitro of ${ }^{\mathbf{3}} \mathrm{H}-\mathrm{SP}$ to different brain \\
& Caudate & Putamen & Cerebellum \\
\hline Left & $0.291 \pm 0.031$ & $0.312 \pm 0.030$ & $0.325 \pm 0.064$ \\
Right & $0.390 \pm 0.095$ & $0.346 \pm 0.046$ & $0.203 \pm 0.017$ \\
$p(t$ test $)$ & NS & NS & NS \\
\hline
\end{tabular}

Units are fmol bound/nM free/mg protein. All values are means \pm SEM for tissues from five baboons assayed two to four times for ${ }^{3} \mathrm{H}$-SP binding not displaceable by $1 \mu \mathrm{M}$ SP. These values are the $n_{1}$ parameter from LIGAND analyses corrected for the amount of protein assayed. 
would not be reasonable. More specific radioligands would be a better approach.

Our analyses assume only one type of dopamine $\mathrm{D}_{2}$ receptor. Recently, evidence for multiple subtypes of $D_{2}$ receptors has appeared (Todd et al., 1989; O'Malley et al., 1990; Sokoloff et al., 1990). All of these subtypes bind SP and eticlopride with high affinity and, if present in baboon brain, would have been measured as $\mathrm{D}_{2}$ sites in this study. Current pharmacological tools cannot distinguish easily among these receptor subtypes. Messenger RNAs for three individual subtypes can be detected with reverse transcription and DNA amplification (O'Malley et al., 1990; Sokoloff et al., 1990). Preliminary studies demonstrate the presence of mRNAs for $\mathrm{D}_{2} \mathrm{~A}_{415}, \mathrm{D} 2 \mathrm{~A}_{444}$, and $\mathrm{D}_{3}$ receptor subtypes in baboon basal ganglia (R. D. Todd, unpublished observations). How the PET-derived variables $k_{1}{ }^{\prime}$ and $k_{-1}$ vary with $\mathrm{D}_{2}$ receptor subtypes is unknown. More specific radioligands for PET could help clarify these issues.

It is important to note that the apparent combined forwardrate constant changed in a consistent manner with pretreatment of the primates with the various unlabeled ligands. Other estimated variables, such as the regional PS for ${ }^{18} \mathrm{~F}-\mathrm{SP}$ and the free fraction in brain tissue, $f_{2}$, did not change consistently. The dissociation rate constant, $k_{-1}$, also appears to have increased after pretreatment, though not as consistently as $k_{1}{ }^{\prime}$. Interpretation of the change in $k_{-1}$ is more difficult because these estimates are not as reliable as those of $k_{1}{ }^{\prime}$. As shown previously (Perlmutter et al., 1989) and confirmed here, the individual cstimates (for cach parameter estimation) of $k_{1}{ }^{\prime}$ have an average coefficient of variation of $9.9 \%( \pm 4.5 \%)$, significantly lower $(p$ $<0.000001$; two-tailed, paired $t$ test) than the average coefficient of variation for $k_{-1}(14.2 \% \pm 5.0 \%)$.

Others have suggested that the cerebellum is not devoid of specific binding sites (Logan et al., 1987; Swart et al., 1990). Our results do not agree with these conclusions. We found no consistent change in the cerebellar lissue-activity curves after pretreatment with eticlopride, ketanserin, or unlabeled SP. If specific sites were present, large doses of these unlabeled ligands would have diminished the uptake of ${ }^{18} \mathrm{~F}$-SP. Furthermore, there was no consistent alteration in $f_{2}$ estimated from the cerebellar data. Part of this discrepancy with other previous reports may stem from species variability; the rat may have specific binding sites for SP in the cerebellum (Swart et al., 1990) that are not present in primates. On the other hand, Logan et al. (1987) also studied baboons using PETT VI in the high-resolution mode and found that pretreatment with $(+)$-butaclamol prior to injection of ${ }^{18} \mathrm{~F}-\mathrm{SP}$ modestly lowered the cerebellar tissue uptake of radioactivity. It is possible that this finding was due to slight misalignment of the animal within the scanner that caused receptor-rich noncerebellar tissue to be included in the "cerebellar" region. Partial volume averaging from nearby occipital lobe, a region that we found with in vitro analysis to contain $S_{2}$ and $\mathrm{D}_{2}$ sites (data not shown), may have contributed to the "apparent specific binding" in cerebellum. We have diminished the effects from nearby occipital lobe by also using the high-resolution mode of PETT VI as well as by careful placement of the animal within the scanner, as previously described (Perlmutter et al., 1989). Finally, our in vitro data also support our contention based on PET data that cerebellum in baboon contains negligible specific binding sites for SP.

Although all of these lines of evidence strongly support the idea that there is a lack of specific binding of ${ }^{18} \mathrm{~F}$-SP in cere- bellum, they do not directly address the issue of a regionally constant $f_{2}$. In this study, we found that nonspecific binding in vitro was invariant across different brain regions, which suggests that $f_{2}$ is regionally invariant. Nevertheless, it is important to realize that the notions of nonspecific binding for in vitro and in vivo methods may be different. Nonspecific binding as measured in vitro is the residual quantity of radioligand remaining in tissue, either homogenate or slices, after the tissue has been exposed to high concentrations of specific antagonists; that is, it is the amount of nondisplaceable radioligand in this tissue, which may include radioligand entrapped in filters, and so on. This is to be distinguished from the displaceable fraction that reflects specific binding. Nonspecific binding in vivo superficially appears similar. Its definition is that amount of radioligand in a compartment that is not free and not bound to specific binding sites as defined in a compartmental model developed to reflect the in vivo behavior of the radioligand (Perlmutter et al., 1986). Operationally in a brain devoid of specific binding sites, the value of the free fraction acts to modify the movement of radioligand from the extravascular space back to the intravascular compartment (Perlmutter et al., 1986). Although nonspecific binding for in vitro and in vivo studies appears similar biologically, operationally it may be different depending upon conditions of the assay. Therefore, these in vitro data do not prove that an in vivo $f_{2}$ estimated for ${ }^{18} \mathrm{~F}-\mathrm{SP}$ in the cerebellum is identical to that in the striatum.

We did not assume that PS for ${ }^{18} \mathrm{~F}-\mathrm{SP}$ is the same for the ccrcbcllum and the striatum, and values of PS were estimated for each region. Recent data suggest that pial vessels in cerebellum have greater intravascular volume than those in the cerebrum (Holash et al., 1990). If the PET ROIs included pial vessels within infolded regions of the cerebellum, then the assumption of a regionally constant PS would be inaccurate, because PS estimates are dependent upon regional CBV (Mintun et al., 1984).

An additional finding of this study (within the limits of statistical power as described in Results) was the lack of left/right differences in specific binding sites in striatum. This was true for both in vivo and in vitro assays and suggests that unilateral lesion studies can use the unperturbed side of a subject as an internal control. Furthermore, these results indicate that sideto-side randomization can be used for control of surgical techniques, without correcting for laterality differences.

This study provides additional operational validation of the non-steady-state measurement of in vivo radioligand binding with PET. Not only has the PET assay performed in a predictable and consistent fashion, but it also gives results that compare closely with those from in vitro binding studies. There was considerable intersubject variability in the estimated apparent combined forward-rate constant (Table 3), but much less intrasubject variability. Previous studies have demonstrated the sensitivity of this in vivo PET technique to a decrease in the number of apparently available specific binding sites for ${ }^{18} \mathrm{~F}-\mathrm{SP}$ (Perlmutter et al., 1989) and to an apparent upregulation of specific binding for ${ }^{18} \mathrm{~F}-\mathrm{SP}$ in a patient with untreated MPTP-induced parkinsonism. Therefore, further investigation with this noninvasive methodology is warranted. Its major limitations continue to be the long duration necessary for each PET study (3$4 \mathrm{hr}$ ) and the fact that it estimates the apparent combined forward-ratc constant for ${ }^{18} \mathrm{~F}-\mathrm{SP}$ rather than the maximum number of specific binding sites $\left(B_{\max }\right)$ itself. 


\section{References}

Baron JC, Samson Y, Crouzel C, Berridge M, Chretien L, Deniker P, Comar D, Agid Y (1985) Pharmacologic studies in man with PET: an investigation using "C-labeled ketanserin, a $5 \mathrm{HT}_{2}$ receptor antagonist. In: Cerebral blood flow and metabolism measurement (Hartmann A, Hoyer S, eds), p. 471-480. Berlin: Springer.

Bennett JP Jr, Wooten GF (1986) Dopamine denervation does not alter in vivo ${ }^{3} \mathrm{H}$-spiperone binding in rat striatum: implication for external imaging for dopamine receptors in Parkinson's disease. Ann Neurol 19:378-383.

Coenen HH, Wienhard K, Stöcklin G, Laufer P, Hebold I, Pawlik G, Heiss W-D (1988) PET measurement of $D_{2}$ and $S_{2}$ receptor binding of 3-N-([2'-18F]fluoroethyl)spiperone in baboon brain. Eur J Nucl Med 14:80-87.

Davis R, Huffman RD (1968) A stereotaxic atlas of the brain of the baboon. Austin, TX: University of Texas Press.

Eckernas S-A, Aquilonius SM, Hartvig P, Hagglund J, Lundqvist H, Nagren K, Langstrom B (1987) Positron emission tomography (PET) in the study of dopamine receptors in the primate brain: evaluation of a kinetic model using ${ }^{11} \mathrm{C}-N$-methyl-spiperone. Acta Neurol Scand 75:168-178.

Farde L, Hall H, Ehrin E, Sedvall G (1986) Quantitative analysis of D2 dopamine receptor binding in the living human brain by PET. Science 231:258-261.

Farde L, Eriksson L, Blomquist G, Halldin C (1989) Kinetic analysis of central [ $\left.{ }^{11} \mathrm{C}\right]$ raclopride binding to D2-dopamine receptors studies with PET - a comparison to the equilibrium analysis. J Cereb Blood Flow Metabol 9:696-708.

Frost JJ, Douglass KH, Mayberg HS, Dannals RF, Links JM, Wilson AA, Ravert HT, Crozier WC, Wagner HN Jr (1989) Multicompartmental analysis of $\left[{ }^{11} \mathrm{C}\right]$-carfentanil binding to opiate receptors in humans measured by positron emission tomography. J Cereb Blood Flow Metabol 9:398-409.

Herscovitch P, Markham J, Raichle ME (1983) Brain blood flow measured with intravenous $\mathrm{H}_{2}^{15} \mathrm{O}$. I. Theory and error analysis. $\mathrm{J}$ Nucl Med 24:782-789.

Holash JA, Sugamori K, Stewart PA (1990) The difference in vascular volume between cerebrum and cerebellum is in the pia mater. $\mathrm{J}$ Cereb Blood Flow Metabol 10:432-434.

Huang S-C, Bahn MM, Barrio JR, Hoffman JM, Satyamurthy N, Hawkins RA, Mazziotta JC, Phelps ME (1989) A double-injection technique for in vivo measurement of dopamine D2-receptor density in monkeys with $3-\left(2^{\prime}\left[{ }^{18} \mathrm{~F}\right]\right.$ fluoroethyl)spiperone and dynamic positron emission tomography. J Cereb Blood Flow Metabol 9:850-858.

Kohler C, Hall $\mathrm{H}$, Gawell L (1986) Regional in vivo binding of the substituted benzamide $\left[{ }^{3} \mathrm{H}\right]$ eticlopride in the rat brain: evidence for selective labelling of dopamine receptors. Eur J Pharmacol 111:217226.

Litton JE, Holte S, Eriksson L (1990) Evaluation of the Karolinska new positron camera system; the Scanditronix PC2048-15B. IEEE Trans Nucl Sci 37:743-748.

Logan J, Wolf AP, Shiue C-Y, Fowler JS (1987) Kinetic modeling of receptor-ligand binding applied to positron emission tomographic studies with neuroleptic tracers. J Neurochem 48:73-83.

Martin WRW, Powers WJ, Raichle ME (1987) Cerebral blood volume measured with inhaled $\mathrm{C}^{\mathrm{is}} \mathrm{O}$ and positron emission tomography. $\mathrm{J}$ Cercb Blood Flow Metabol 7:421-426.

Maziere B, Loc'H C, Stulzaft O, Hantraye P, Ottaviani M, Comar D, Maziere M (1986) [ $\left.{ }^{76} \mathrm{Br}\right]$ bromolisuride: a new tool for quantitative in vivo imaging of D-2 receptors. Eur J Pharmacol 127:239-247.

Mazziotta JC, Phelps ME, Plummer D, Kuhl DE (1981) Quantitation in positron emission computed tomography: V. Physical-anatomical effects. J Comput Assist Tomogr 5:734-743.

Mintun MA, Raichle ME, Kilbourn MR, Wooten GF, Welch MJ (1984) A quantitative model for the in vivo assessment of drug binding sites with positron emission tomography. Ann Neurol 15:217-227.

Moerlein SM, Perlmutter JS (1990) Evaluation of N- $\omega-[\mathrm{F}$ - 18]fluoroethylketanserin for measurement of in-vivo S-2 receptor binding with PET. J Nucl Med 31:780.

Munson PJ, Rodbard D (1980) LIGAND: A versatile computerized approach for characterization of ligand-binding systems. Anal Biochem 107:220-239.

O'Malley KL, Mack KJ, Gandelman K-Y, Todd RD (1990) Organization and expression of the rat D2A receptor gene. Biochemistry 29: 1367-1371.

Perlmutter JS, Raichle ME (1986) In vitro or in vivo receptor binding: where does the truth lie? Ann Neurol 19:384-385.

Perlmutter JS, Larson KB, Raichle ME, Markham J, Mintun MA, Kilbourn MR, Raichle ME, Welch MJ (1986) Strategies for in vivo measurement of receptor binding using positron emission tomography. J Cereb Blood Flow Metabol 6:154-169.

Perlmutter JS, Kilbourn MR, Welch MJ, Raichle ME (1987) MPTPinduced up-regulation of in vivo dopaminergic radioligand-receptor binding in humans. Neurology 37:1575-1579.

Perlmutter JS, Kilbourn MR, Welch MJ, Raichle ME (1989) Nonsteady-state measurement of in vivo receptor binding with positron emission tomography: “dose-response" analysis. J Neurosci 9:23442352.

Pogun S, Duelfer T, Corley EG, Dannals RF, Dranbauer BJ, Scheffel U, Waud JM, O'Brien HA, Kuhar MJ, Burns HD, Wagner HN (1982) Radiolabeled spiperone analogues for imaging dopamine receptors. In: Nuclear medicine in biology, Vol 4 (Raynaud C, ed), pp 36063609. Oxford: Pergamon.

Raichle ME, Martin WR, Herscovitch P, Mintun MA, Markham J (1983) Brain blood flow measured with intravenous $\mathrm{H}_{2}{ }^{15} \mathrm{O}$. II. Implementation and validation. J Nucl Med 24:790-798.

Seeman P, Ulpian C, Wreggett KA, Wells JW (1984) Dopamine receptor parameters detected by $\left[{ }^{3} \mathrm{H}\right]$ spiperone depend on tissue concentration: analysis and examples. J Neurochem 43:221-235.

Sokoloff P, Giras B, Martres M-P, Bouthenet M-L, Schwartz J-C (1990) Molecular cloning and characterization of a novel dopamine receptor $\left(D_{3}\right)$ as a target for neuroleptics. Nature 347:146-151.

Spinks TJ, Jones T, Gilardi MC, Heather JD (1988) Physical performance of the latest generation of commercial positron scanner. IEEE Trans Nucl Sci 35:721-725.

Swart JAA, van der Werf JF, Wiegman T, Paans AMJ, Vaalburg W, Korf J (1990) In vivo binding of spiperone and $N$-methylspiperone to dopaminergic and serotonergic sites in the rate brain: multiple modeling and implications for PET scanning. J Cereb Blood Flow Metabol 10:297-306.

Ter-Pogossian MM, Ficke DC, Hood JT, Yamamoto M, Mullani NA (1982) PETT VI: a positron emission tomograph utilizing cesium fluoride scintillation detectors. J Comput Assist Tomogr 6:125-133.

Todd RD, Bauer PA (1988) Ascorbate modulates $5-\left[{ }^{3} \mathrm{H}\right] \mathrm{hy}$ droxytryptamine binding to central $5-\mathrm{HT}_{3}$ sites in bovine frontal cortex. J Neurochem 50:1505-1512.

Todd RD, Khurana TS, Sajovic P, Stone KR, O'Malley KL (1989) Cloning of ligand-specific cell lines via gene transfer identification of a $D_{2}$ dopamine receptor subtype. Proc Natl Acad Sci USA 86:1013410138.

Videen TO, Perlmutter JS, Herscovitch P, Raichle ME (1987) Brain blood volume, flow and oxygen utilization mcasured with $0-15$ radiotracers and positron emission tomography: revised metabolic computations. J Cereb Blood Flow Metabol 7:513-516.

Wong DF, Gjedde A, Wagner HN Jr (1986a) Quantification of neuroreceptors in the living human brain. I. Irreversible binding of ligands. J Cereb Blood Flow Metabol 6:137-146.

Wong DF, Gjedde A, Wagner HN Jr, Dannals RF, Douglass KH, Links JM, Kuhar MJ (1986b) Quantification of neuroreceptors in the living human brain. II. Inhibition studies of receptor density and affinity. J Cereb Blood Flow Metabol 6:147-153.

Yamamoto M, Ficke DC, Ter-Pogossian MM (1982) Performance study of PETT VI, a positron emission tomograph with 288 cesium fluoride detectors. IEEE Trans Nucl Sci 29:529-533. 